\title{
PENGARUH KUALITAS PRODUK DAN HARGA TERHADAP LOYALITAS PELANGGAN PADA PELANGGAN PRODUK FLORIDINA
}

\author{
(Studi Kasus Pada PT. Multi Inti Parahiyangan Cabang Jatibarang-Widasari Kab. \\ Indramayu) \\ The Effect of product quality and prices on customer loyalty to Floridina product customers. \\ (Case Study at PT. Multi Inti Parahiyangan Jatibarang Branch -Widasari, Indramayu Regency)
}

\author{
Surianti \\ Manajemen FE Unwir \\ nochyanti@gmail.com
}

\begin{abstract}
ABSTRAK
Penelitian ini bertujuan untuk mengetahui pengaruh kualitas produk dan harga terhadap loyalitas pelanggan pada produk Floridina di PT. Multi Inti Parahiyangan Depo Jatibarang, Indramayu. Data diperoleh dengan observasi, wawancara dan kuisioner terhadap 94 responden pelanggan PT. Multi Inti Parahiyangan.

Kualitas produk Floridina pada PT. Multi Inti Parahiyangan yaitu mencapai $\mathbf{7 9 , 9 0 \%}$ termasuk kedalam kategori baik. Tingkat harga pada produk Floridina pada PT. Multi Inti Parahiyangan yaitu mencapai 90,85\% termasuk ke dalam kategori Sangat Baik. Loyalitas pelanggan pada produk Floridina di PT. Multi Inti Parahiyangan yaitu mencapai 88,66 \% termasuk ke dalam kategori Sangat Baik. Hasil dari persamaan analisis regresi berganda untuk dua prediktor diperoleh $\mathrm{Y}=(-6,437)+1,079 \mathrm{X} 1+$ $(-0,0125)$ X2

Hasil analisis korelasi X1 terhadap Y yaitu $r$ x1y $=0,12$ membuktikan bahwa terdapat pengaruh kualitas produk terhadap loyalitas pelanggan yang sangat rendah dan positif. Sedangkan besarnya pengaruh X1 terhadap Y dapat dilihat dari hasil koefisien determinasi kd $\mathrm{x} 1 \mathrm{y}=$ sebesar $1,45 \%$ dan sisanya $98,55 \%$ dipengaruhi oleh faktor lain yang tidak diteliti. Hasil Uji hipotesis dengan menggunakan uji $(t)$ diperoleh $t$ hitung $x 1 y$ $=1,160$ dengan ttabel $=1,980$ sehingga $(1,160$ $<$ 1,980) maka Hipotesis awal diterima dan Hipotesis alternatif ditolak.

Hasil analisis korelasi X2 terhadap $Y$ yaitu $r$ $x 2 y=(-0,81)$ membuktikan bahwa terdapat hubungan pengaruh harga terhadap loyalitas pelanggan yang sangat kuat dan negatif. Sedangkan besarnya pengaruh $\mathrm{X} 2$ terhadap $Y$ dapat diihat dari hasil koefisien determinasi $\mathrm{kd} \times 2 \mathrm{y}=$ sebesar $65,61 \%$
\end{abstract}

Sedangkan sisanya 34,39\% dipengaruhi oleh faktor lain yang tidak diteliti. Uji hipotesis dengan menggunakan uji (t) diperoleh $t$ hitung $x 2 y=(-13,324)$ dengan ttabel $=1,980$ sehingga $(-13,324<1,980)$ maka Hipotesis awal diterima dan Hipotesis alternatif ditolak.

Hasil analisis korelasi X1 dan X2 terhadap Y yaitu $r$ x1 $x 2 y=0,342$ menunjukkan bahwa terdapat pengaruh kualitas produk dan harga terhadap loyalitas pelanggan yang rendah dan positif. Dan besarnya pengaruh X1 dan X2 terhadap Y dari hasil koefisien determinasi $k d x 1 \times 2 y=11,67 \%$ sedangkan sisanya $88,33 \%$ dipengaruhi oleh faktorfaktor lainnya yang tidak diteliti.

Uji hipotesis dengan menggunakan uji (t) diperoleh $t$ hitung $x 1 \times 2 y=35,633$ dengan ttabel $=1,980$ sehingga $(35,633>1,980)$ maka Hipotesis alternatif diterima dan Hipotesis awal ditolak.

Kata Kunci: Kualitas Produk, Harga, Loyalitas Pelanggan.

\section{ABSTRACT}

This study aims to determine the effect of product quality and price on customer loyalty on Floridina products at PT. Multi Inti Parahiyangan Depo Jatibarang, Indramayu. Data obtained by observation, interviews and questionnaires on 94 customer respondents PT. Multi Inti Parahiyangan.

Floridina product quality at PT. Multi Inti Parahiyangan which reached $\mathbf{7 9 . 9 0 \%}$ included in the good category. Price level on Floridina products at PT. Multi Inti Parahiyangan which reached $90.85 \%$ included in the Very Good category. Customer loyalty to Floridina products at PT. Multi Inti Parahiyangan which reached $\mathbf{8 8 . 6 6 \%}$ included in the Very Good category. The results of the multiple regression 
analysis equation for two predictors obtained $Y=(-6,437)+1,079 X 1+(-0,0125)$ $\mathrm{X} 2$

The results of the $\mathrm{X} 1$ correlation analysis of $Y$, namely $r \times 1 y=0.12$ prove that there is an influence of product quality on customer loyalty that is very low and positive. While the magnitude of the influence of $\mathrm{X} 1$ on $\mathrm{Y}$ can be seen from the results of the coefficient of determination $\mathrm{k} 1 \mathrm{x}=1.45 \%$ and the remaining $98.55 \%$ is influenced by other factors not examined. Hypothesis test results using the test $(t)$ obtained $t$ count $x 1 y=1.160$ with $\mathrm{t}$ table $=1.980$ so $(1.160<1.980)$ then the initial hypothesis is accepted and the alternative hypothesis is rejected.

The results of the $\mathrm{X} 2$ correlation analysis on $Y$, namely $r \times 2 y=(-0.81)$ prove that there is a relationship between the effect of price on customer loyalty which is very strong and negative. While the magnitude of the effect of $X 2$ on $Y$ can be seen from the results of the coefficient of determination of $\mathbf{x} 2 y=$ equal to $65.61 \%$ while the remaining $34.39 \%$ is influenced by other factors not examined. Hypothesis testing using the test $(t)$ obtained $t$ count $x 2 y=(-13,324)$ with $t$ table $=1,980$ so that $(-13,324<1,980)$ then the initial hypothesis was accepted and the alternative hypothesis was rejected.

The results of the $\mathrm{X} 1$ and $\mathrm{X} 2$ correlation analysis of $Y$ ie $r \times 1 \times 2 y=0.342$ indicate that there is an influence of product quality and price on low and positive customer loyalty. And the magnitude of the influence of X1 and $\mathrm{X} 2$ on $Y$ from the coefficient of determination $\mathrm{kd} \times 1 \times 2 \mathrm{y}=\mathbf{1 1 . 6 7 \%}$ while the remaining $88.33 \%$ is influenced by other factors not examined.

Hypothesis testing using the test $(t)$ obtained $t$ count $x 1 x 2 y=35,633$ with $t$ table $=1,980$ so $(35,633>1,980)$ then the alternative hypothesis was accepted and the initial hypothesis was rejected.

Key Words: Product Quality, Price, Customer Loyalty.

\section{PENDAHULUAN}

Pada saat dewasa ini banyak perusahaan yang menghasilkan produk dengan jenis dan kegunaan yang sama akan tetapi dengan harga, fitur produk, dan layanan yang berbeda. Keadaan ini tentu saja memaksa para pengusaha untuk menggunakan berbagai cara dalam strategi pemasarannya. Semakin banyaknya persaingan membuat perusahaan satu dengan yang lainnya saling berlomba dan perusahaan tidak akan berhenti melakukan strategi demi mencapai tujuan dan kelangsungan perusahaan. Tujuan perusahaan melakukan kegiatan pemasaran untuk memenuhi kebutuhan dan keinginan konsumen dengan produk yang berkualitas, karena produk yang berkualitas banyak diminati oleh konsumen sehingga konsumen yakin bahwa produk tersebut yang terbaik dan membuat konsumen bersedia melakukan pembelian berulang-ulang. Konsumen bersikap lebih selektif dan kritis dalam memilih produk yang akan dibeli. Konsumen tidak lagi membeli produk sekedar berdasarkan pertimbangan wujud fisik produk saja, namun juga termasuk segala aspek pelayanan yang melekat pada produk tersebutu, mulai dari tahap pembelian sampai pada tahap pasca pembelian.

Pada tahap pasca pembelian yang menjadi pertimbangan konsumen diantaranya adalah harga yang murah dan kualitas produk yang baik untuk mencapai kepuasan dan perusahaan berharap konsumen akan melakukan 
Surianti

pembelian berulang. Pembelian konsumen secara berulang ini menciptakan loyalitas pada satu produk yang diinginkannya. Perusahaan berharap dengan menciptakan konsumen yang loyal dapat menjadi aset yang sangat bernilai bagi perusahaan. Dipertahankannya konsumen yang loyal dapat mengurangi usaha mencari konsumen baru yang berarti memberikan umpan balik positif kepada perusahaan. Perusahaan dapat lebih melakukan penghematan biaya dalam mempertahankan konsumen yang lama daripada mencari konsumen baru. Loyalitas pelanggan menjadi hal mutlak yang diperlukan di lini bisnis apapun, temasuk bisnis industri toiletries dan industri makanan.

Berawal dari menanggapi kebutuhan dan keinginan masyarakat akan berbagai produk dan jasa yang semakin beragam "Group Wings" yang bermula hanya memproduksi dan memasarkan produk toiletris, kini Wings Group telah menambah ke industri makanan. Wings juga memperluas jaringan distribusi selama periode ini, ke titik di mana produk yang tersedia di hampir setiap kota dan desa di setiap provinsi negara itu, situasi yang ada sampai hari ini. Wings saat ini memperluas lini produknya termasuk minuman dan mie instan. Salah satu produk minuman yang diproduksi wings adalah produk minuman dalam kemasan dengan rasa jeruk dan bulir jeruk asli dari Florida Amerika Serikat yaitu Floridina.

Berdasarkan uraian serta penjelasan pada latar belakang maka rumusan masalah dalam penelitian ini adalah sebagai berikut :

1. Bagaimana kualitas produk Floridina di PT. Multi Inti Parahiyangan?

2. Bagaimana harga produk Floridina di PT. Multi Inti Parahiyangan ?

3. Bagaimana loyalitas pelanggan Floridina di PT. Multi Inti Parahiyangan?

4. Bagaimana pengaruh kualitas produk terhadap loyalitas pelanggan Floridina di PT. Multi Inti Parahiyangan?

5. Bagaimana pengaruh harga terhadap loyalitas pelanggan Floridina di PT. Multi Inti Parahiyangan?

6. Bagaimana pengaruh kualitas produk dan harga terhadap loyalitas pelanggan Floridina di PT. Multi Inti Parahiyangan? 


\section{TINJAUAN PUSTAKA}

Kualitas Produk Menurut Nembah

F. Hartimbul Ginting (2011:96) mengungkapkan bahwa "Kualitas

Produk adalah kemampuan suatu produk untuk memperagakan fungsinya. Ini menyangkut ketahanan umum produk, reliabilitas, presisi, kemudahan pengoperasian dan perbaikan serta atribut bernilai lainnya".

Sedangkan menurut Thamrin Abdullah dan Francis Tantri (2012:159) mengemukakan bahwa "Kualitas Produk adalah kemampuan produk untuk melaksanakan fungsinya. Termasuk di dalamnya keawetan, keandalan, ketepatan, kemudahan dipergunakan dan diperbaiki, serta atribut bernilai lainnya”. Dan menurut Juran Hunt dalam M.N. Nasution (2010:2) mendefinisikan bahwa "Kualitas Produk adalah kecocokan penggunaan produk (fitness for use) untuk memenuhi kebutuhan dan kepuasan pelanggan. Kecocokan penggunaan itu didasarkan atas lima ciri utama yaitu teknologi, psikologis, waktu, kontraktual, dan Etika”.

Dari definisi pendapat para ahli diatas peneliti merangkum mengambil kesimpulan bahwa kualitas produk adalah kemampuan suatu produk dalam memperagakan fungsinya tentang ketahanan umum produk, keandalan, ketepatan, kemudahan penggunaan , kemudahan dalam perbaikan serta berbagai atribut yang bernilai lainnya dalam memenuhi kebutuhan dan kepuasan

Harga adalah komponen bauran pemasaran yang menghasilkan pendapatan, sedangkan yang lainnya menghasilkan biaya. Pemahami terhadap konsumen bagaimana konsumen memahami dan menerima harga suatu produk atau jasa, merupakan prioritas pemasaran yang penting karena berpengaruh langsung terhadap laba perusahaan. Harga mengkomunikasikan positioning nilai yang dimaksud dari produk atau merek perusahaan ke pasar.

Fandy Tjipto (2015:289), mendefinisikan harga dari sudut pandang pemasaran bahwa "Harga merupakan satuan moneter atau ukuran lainnya (termasuk barang dan jasa lainnya) yang ditukarkan agar memperoleh hak kepemilikan atau penggunaan suatu barang atau jasa”.

Sedangkan Herry Achmad Buchory dan H. Djaslim Saladin (2010:159) menyatakan bahwa "Harga adalah komponen bauran pemasaran yang menghasilkan pendapatan 
Surianti

sedangkan yang lainnya menghasilkan biaya".

Menurut Grewal dan Levy dalam Fandy Tjipto (2015:290) mendefinisikan bahwa "Harga sebagai pengorbanan keseluruhan yang bersedia dilakukan konsumen dalam rangka mendapatkan produk atau jasa spesifik".

Berdasarkan pendapat diatas peneliti mengambil kesimpulan bahwa harga adalah satuan moneter, atau ukuran lainnya untuk menggunakan barang atau jasa atau pengorbanan yang dilakukan konsumen dalam bentuk biaya untuk mendapatkan produk atau jasa spesifik untuk menghasilkan pendapatan.

Menurut Fandy Tjiptono (2015:293) ada 8 (delapan) tujuan penetapan harga, yaitu:

1. Berorientasi pada laba

2. Berorientasi pada Volume

3. Permintaan pasar

4. Pangsa pasar

5. Aliran kas (cash flow)

6. Menyamai pesaing

7. Prestise

8. Status quo

Pelanggan adalah orang-orang yang kegiatannya membeli dan menggunakan suatu produk, baik barang maupun jasa, secara terus menerus. Pelanggan atau pemakai suatu produk adalah orang-orang yang berhubungan secara langsung maupun tidak langsung dengan perusahaanperusahaan bisnis, contohnya adalah pemasok. Pada dasarnya tujuan dari sebuah bisnis adalah untuk menciptakan para pelanggan yang puas. Terciptanya kepuasan pelanggan dapat memberikan beberapa manfaat, diantaranya hubungan antara perusahaan dan pelanggannya menjadi harmonis, memberikan dasar-dasar yang baik bagi pembelian ulang dan terciptanya loyalitas pelanggan.

Menurut Oliver dalam Eta Mamang Sangadji dan Sopiah (2013:104) menyatakan bahwa "Loyalitas adalah komitmen pelanggan bertahan secara mendalam untuk berlangganan kembali atau melakukan pembelian ulang produk atau jasa terpilih secara konsisten di masa yang akan datang, meskipun pengaruh situasi dan usaha-usaha pemasaran mempuyai potensi untuk menyebabkan perubahan perilaku".

Menurut Morais dalam Eta Mamang Sangadji dan Sopiah (2013:104) mendefinisikan loyalitas pelanggan bahwa "Loyalitas pelanggan adalah komitmen pelanggan terhadap suatu merek toko, atau pemasok, 
berdasarkan sikap yang sangat positif dan tercermin dalam pembelian ulang yang konsisten"

Sedangkan menurut Fandy Tjiptono (2005:385), "Loyalitas pelanggan adalah situasi ideal yang paling diharapkan para pemasar, dimana konsumen bersifat positif terhadap produk atau produsen (penyedia jasa) dan disertai pola pembelian ulang yang konsisten".

Dari beberapa pendapat ahli peneliti merangkum bahwa loyalitas pelanggan adalah komitmen pelanggan terhadap suatu merek tokoatau pemasok berdasarkan sikap yang sangat positif dan tercermin dalam pembelian ulang yang konsisten.

Menurut Tjiptono dalam Eta Mamang Sangadji dan Sopiah (2013:105) terdapat 6 (enam) indikator yang bisa digunakan untuk mengukur loyalitas konsumen, yaitu:

1. Pembelian ulang;

2. Kebiasaan mengkonsumsi merek;

3. Rasa suka yang besar pada merek;

4. Ketetapan pada merek;

5. Keyakinan bahwa merek tertentu merek yang terbaik;

6. Perekomendasian merek pada orang lain.

\section{METODOLOGI PENELITIAN}

Dalam melakukan penelitian ini peneliti menggunakan Pendekatan kualitatif. Menurut Rully dan Poppy (2014:29) menjelaskan "Pendekatan kualitatif adalah pendekatan penelitian yang diarahkan untuk pencapaian tujuan memperoleh penjelasan secara mendalam atas penerapan sebuah teori. Dengan demikian, lebih banyak menggunakan berpikir induksi (empiris)."

Metode analisis yang digunakan dalam penelitian ini adalah metode analisis deskriptif dan verifikatif. Analisis deskripptif dilakukan untuk memperoleh kejelasan tentang ciri-ciri variable yang diteliti. Analisis Verivikatif dilakukan untuk menguji hipotesis dengan menggunakan alat uji statistik.

Pengumpulan data yang
dilakukan oleh peneliti untuk mengetahui berbagai sumber baik sumber primer maupun sumber sekunder. Sumber primer merupakan sumber yang peneliti dapatkan secara langsung dari pelanggan melalui pembagian angket kepada pelanggan dengan ketentuan kuota berdasarkan perhitungan skala likert. Sumber sekunder merupakan sumber yang secara tidak langsung memberikan data 
Surianti

kepada peneliti. Sumber sekunder penulis dapatkan dari berbagai literature serta data langsung dari perusahaan internal.

\section{PEMBAHASAN}

1. Analisis Regresi Sederhana

Analisis regresi sederhana dilakukan peneliti bertujuan untuk mengetahui pengaruh kualitas produk (X1) terhadap Loyalitas Pelanggan (Y). Berdasarkan 94 Responden yang digunakan sebagai sumber data dan berdasarkan pada tabel penolong korelasi dan regresi dapat diketahui sebagai berikut:

$\mathrm{N}=94 \quad \sum \mathrm{X}_{1}=5258 \quad \sum \mathrm{Y}=4584$

$\sum \mathrm{X}_{1} \mathrm{Y}=256568 \quad \sum \mathrm{X}_{1}^{2}=296528$

$\sum Y^{2}=224224$

Persamaan regresi sederhana:

$$
\begin{aligned}
& \mathrm{a}=\frac{\left(\sum Y\right)\left(\sum x 1^{2}\right)-\left(\sum x_{1}\right)\left(\sum x_{1} y\right)}{n\left(\sum x 1^{2}\right)-\left(\sum x_{1}\right)^{2}} \\
& \mathrm{a}=\frac{(4584)(296528)-(5258)(256568)}{94(296528)-(5258)^{2}}
\end{aligned}
$$$$
\mathrm{a}=45,14
$$$$
\mathrm{b}_{1}=\frac{n\left(\sum x_{1} y\right)-\left(\sum x_{1}\right)\left(\sum y\right)}{n\left(\sum x 1^{2}\right)-\left(\sum x_{1}\right)^{2}}
$$$$
\mathrm{b}_{1}=\frac{94(256568)-(5258)(4584)}{94(296528)-(5258)^{2}}
$$$$
\mathrm{b}_{1}=0,065
$$

Dari hasil perhitungan diatas, maka didapat persamaan regresi sederhana dari variabel $\mathrm{X}_{1}$ terhadap $\mathrm{Y}$ sebagai berikut :

$\begin{array}{r}\mathrm{Y}=\mathrm{a}+\mathrm{b}_{1} \mathrm{X}_{1} \\ \text { Berdasarkan }\end{array} \mathrm{Y}=45,14+0,065$
dapat dilihat bahwa setiap peningkatan yang terjadi pada variabel kualitas produk $\left(\mathrm{X}_{1}\right)$ menyebabkan peningkatan pula pada variabel Loyalitas pelanggan (Y).

Analisis regresi sederhana juga peneliti lakukan pada terhadap pengaruh Harga $\left(\mathrm{X}_{2}\right)$ terhadap Loyalitas Pelanggan (Y). Berdasarkan 94 Responden yang digunakan sebagai sumber data dan berdasarkan pada tabel penolong korelasi dan regresi yang terlampir dibawah ini:

$\mathrm{N}=94 \quad \sum \mathrm{X}_{2}=3416 \quad \sum \mathrm{Y}=4584$

$\sum \mathrm{X}_{2} \mathrm{Y}=166550 \quad \sum \mathrm{X}_{2}{ }^{2}=124400$

$$
\sum \mathrm{Y}^{2}=224224
$$

Persamaan regresi sederhana yaitu :

$$
\begin{aligned}
& \mathrm{a}=\frac{\left(\sum Y\right)\left(\sum x_{2}^{2}\right)-\left(\sum x_{2}\right)\left(\sum x 2 y\right)}{n\left(\sum x_{2}^{2}\right)-\left(\sum x_{2}\right)^{2}} \\
& \mathrm{a}=\frac{(4584)(124400)-(3416)(166550)}{94\left(124400-(3416)^{2}\right.} \\
& \mathrm{a}=53,57 \\
& \mathrm{~b}_{2}=\frac{n\left(\sum x_{2} y\right)-\left(\sum x_{2}\right)\left(\sum y\right)}{n\left(\sum x_{2}^{2}\right)-\left(\sum x_{2}\right)^{2}} \\
& \mathrm{~b}_{2}=\frac{94(166550)-(3416)(4584)}{94(124400)-(3416)^{2}} \\
& \mathrm{~b}_{2}=(-0,132)
\end{aligned}
$$

Dari hasil perhitungan diatas, maka didapat persamaan regresi sederhana dari variabel $\mathrm{X}_{2}$ terhadap $\mathrm{Y}$ sebagai berikut :

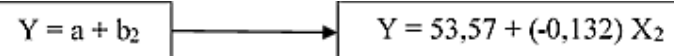

Berdasarkan persamaan regresi diatas dapat disimpulkan bahwa setiap 
peningkatan yang terjadi pada variabel Harga $\left(\mathrm{X}_{2}\right)$ menyebabkan penurunan pada variabel Loyalitas pelanggan (Y), sedangkan jika variabel harga mengalami penurunan maka terjadi peningkatan pada variabel Loyalitas pelanggan (Y).

Sedangkan hasil dari Analisis regresi sederhana pada pengaruh kualitas produk $\left(\mathrm{X}_{1}\right)$ dan Harga $\left(\mathrm{X}_{2}\right)$ terhadap Loyalitas Pelanggan (Y). Berdasarkan 94 Responden yang digunakan sebagai sumber data dan berdasarkan pada tabel penolong korelasi dan regresi yang terlampir dapat diketahui sebagai berikut :

$\sum \mathrm{X}_{1}=5258 \quad \sum \mathrm{X}_{2}=3416$

$\sum Y=4584 \quad \mathrm{~N}=94$

$\sum X_{1} X_{2}=191049$

$\sum \mathrm{X}_{1} \mathrm{Y}=256568 \quad \sum \mathrm{X}_{2} \mathrm{Y}=166550$

$\sum \mathrm{X}_{1}^{2}=296528 \sum \mathrm{X}_{2}^{2}=$

$124400 \sum Y^{2}=224224$

Setelah nilai $a, b_{1}$ dan $b_{2}$ di dapat, maka persamaan regresinya yaitu :

$Y=(-6,437)+1,079 X_{1}+(-0,0125) X_{2}$

Dari persamaan regresi diatas dapat diketahui bahwa nilai konstanta sebesar $(-6,437)$ dan itu menunjukkan jika kualitas produk $\left(\mathrm{X}_{1}\right)$ dan Harga $\left(\mathrm{X}_{2}\right)=0$ atau tidak ada, maka Loyalitas Pelanggan (Y) akan berkurang yaitu (6,437). Koefisien regresi untuk Kualitas Produk $\left(\mathrm{X}_{1}\right)$ sebesar 1,079 yang memiliki hubungan positif terhadap loyalitas pelanggan (Y), yaitu apabila kualitas produk ditingkatkan maka akan meningkat pula loyalitas pelanggan. Dan untuk koefisien regresi variabel Harga $\left(\mathrm{X}_{2}\right)$ yaitu sebesar $(-0,0125)$ yang memiliki hubungan negatif terhadap Loyalitas pelanggan, yaitu apabila terjadi peningkatan terhadap harga maka loyalitas pelanggan akan menurun, sedangkan apabila terjadi penurunan harga maka akan terjadi peningkatan loyalitas pelanggan.

Jadi apabila terjadi peningkatan satu-satu variabel kualitas produk $\left(\mathrm{X}_{1}\right)$ dan harga $\left(\mathrm{X}_{2}\right)$ menyebabkan peningkatan pada variabel Loyalitas pelanggan (Y) yaitu sebesar $(1,079)$ yang dipengaruhi oleh variabel kualitas produk dan menyebabkan penurunan pada loyalitas pelanggan sebesar (0.0125) yang dipengaruhi oleh variabel harga $\left(\mathrm{X}_{2}\right)$.

Untuk mengetahui sejauh mana hubungan antar variabel peneliti menggunakan Uji Korelasi Regresi Sederhana.

Berdasarkan data dari tabel penolong korelasi dapat diketahui sebagai berikut :

$\sum \mathrm{X}_{1}=5258 \quad \sum \mathrm{X}_{2}=3416$

$\sum \mathrm{Y}=4584$

$\sum \mathrm{X}_{1} \mathrm{X}_{2}=191049 \quad \sum \mathrm{X}_{1} \mathrm{Y}=256568$

$$
\sum X_{2} Y=166550
$$




$$
\begin{aligned}
& \sum \mathrm{X}_{1}{ }^{2}=296528 \sum \mathrm{X}_{2}{ }^{2}=124400 \\
& \sum \mathrm{Y}^{2}=224224
\end{aligned}
$$

Analisis Korelasi kualitas produk $\left(\mathrm{X}_{1}\right)$ terhadap Loyalitas Pelanggan (Y)

$$
\begin{aligned}
& =\frac{r x_{1} y}{\sqrt{\left(n \sum X_{1}^{2}-\left(\sum X_{1}\right)^{2}\right)\left(n \sum x^{2}-\left(\sum Y\right)^{2}\right)}} \\
& \mathbf{r} \mathbf{x}_{1 \mathrm{y}}= \\
& \frac{94.280686-(5258)(5015)}{\sqrt{\left(94.296528-74(5258)^{2}\right)\left(94.268249-(5015)^{2}\right)}} \\
& \mathrm{rx}_{1 \mathrm{y}}=0,12
\end{aligned}
$$

Nilai korelasi Kualitas Produk $\left(\mathrm{X}_{1}\right)$ terhadap Loyalitas pelanggan (Y) sebesar 0,12. Artinya Kualitas Produk terhadap loyalitas mempunyai hubungan yang rendah dan positif.

Korelasi $\mathrm{X}_{2}$ terhadap $\mathrm{Y}$

$$
\begin{gathered}
=\frac{r x_{2} y}{\sqrt{\left(n \sum X_{2}^{2}-\left(\sum X_{2}\right)^{2}\right)\left(n \sum Y^{2}-\left(\sum Y\right)^{2}\right)}} \\
\quad r x_{2 y} \quad= \\
\frac{94.227216-(4259)(5015)}{\sqrt{\left(94.193235-(4259)^{2}\right)\left(94.268249-(5015)^{2}\right)}} \\
\quad r \mathbf{x}_{\mathbf{2 y}} \quad=(-\mathbf{0}, \mathbf{8 1})
\end{gathered}
$$

Nilai korelasi Kualitas Produk $\left(\mathrm{X}_{2}\right)$ terhadap Loyalitas pelanggan (Y) sebesar (-0,81). Artinya Kualitas Produk terhadap loyalitas mempunyai hubungan sangat dan negative karena $r$ mendekati (-1).

Korelasi $\mathrm{X}_{1}$ dan $\mathrm{X}_{2}$ terhadap $\mathrm{Y}$

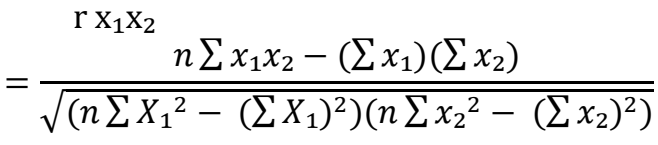

$$
\begin{aligned}
& r x_{1} x_{2}= \\
& \frac{94.238224-(5258)(4259)}{\sqrt{\left(94.296528-(5258)^{2}\right)\left(94.193235-(4259)^{2}\right)}}
\end{aligned}
$$

$\mathbf{r}_{\mathrm{x} 1 \times 2}=(-0,36)$

Didapatkan nilai korelasi $\mathrm{X}_{1}$ terhadap Y $\left(\mathbf{r} \mathbf{x}_{\mathbf{1 y}}\right)=\mathbf{0 , 1 2}$, nilai korelasi $\mathrm{X}_{2}$ terhadap $\left.\mathrm{Y}\left(\mathbf{r} \mathbf{x}_{\mathbf{2}}\right)=\mathbf{( - 0 , 8 1}\right)$ dan nilai korelasi $\mathrm{X}_{1}$ terhadap $\mathrm{X}_{2}\left(\begin{array}{l}\mathbf{r} \\ \mathbf{x} \mathbf{1} \mathbf{2})\end{array}\right)=(-$ 0,36).

Dan untuk mencari nilai korelasi variabel $\left(\mathrm{X}_{1}\right)$ Kualitas Produk dan Variabel $\left(\mathrm{X}_{2}\right)$ Harga terhadap Variabel (Y) Loyalitas Pelanggan secara simultan atau bersama-sama yaitu dengan menggunakan rumus korelasi berganda (Rank Spearman).

Rumus yang digunakan adalah sebagai berikut :

$\mathrm{r}_{\mathrm{y} \times 1 \times 2}=\sqrt{\frac{r y x 1^{2}+r y x 2^{2}-2 r y x 2 r x 1 \times 2}{1-r \times 1 \times 2^{2}}}$
$\mathrm{r}_{\mathrm{y} \times 1 \times 2}=\sqrt{\frac{(0,12)^{2}+(-0,82)^{2}-2(-0,82)(-0,36)}{1-(-0,36)^{2}}}$

$\mathrm{r}_{\mathrm{y} \times 1 \times 2}=\sqrt{0,117}$

$\mathbf{r}_{\mathrm{y} \times 1 \times 2}=0,342$

Dari perhitungan diatas diperoleh $\mathrm{R}_{\mathrm{y} \times 1 \times 2}=\mathbf{0 , 3 4 2}$ artinya kualitas produk dan harga terhadap loyalitas pelanggan pada produk Floridina di PT. Multi Inti Parahiyangan Depo Jatibarang termasuk dalam kategori cukup dan positif. 
Untuk mengetahui seberapa besar kontribusi yang diberikan varibel terikat terhadap variabel bebas peneliti dapat menyimpulkan laporannya dibawah ini: Koefisien Determinasi $\mathrm{X}_{1}$ terhadap $\mathrm{Y}$

Untuk mengetahui seberapa besar konstribusi yang diberikan kualitas produk terhadap loyalitas pelanggan maka dapat disimpulkan dengan koefisien determinasi sebagai berikut :

$\mathrm{Kd}=\left(\mathrm{r}_{1 \mathrm{y}}\right)^{2} \times 100 \%$

$\mathrm{Kd}=(0,12)^{2} \times 100 \%$

$\mathrm{Kd}_{\mathrm{x} 1 \mathrm{y}}=1,45 \%$

Berdasarkan perhitungan diatas dapat disimpulkan bahwa, kualitas produk terhadap loyalitas pelanggan memiliki konstribusi sebesar 1,45\% Sedangkan sisanya $98,55 \%$ dipengaruhi oleh faktor-faktor lainnya yang tidak diteliti.

Koefisien Determinasi $\mathrm{X}_{2}$ terhadap $\mathrm{Y}$

Untuk mengetahui seberapa besar konstribusi yang diberikan harga terhadap loyalitas pelanggan maka dapat disimpulkan dengan koefisien determinasi sebagai berikut :

$\mathrm{Kd}$

$$
=\left(\mathrm{r}_{2 \mathrm{y}}\right)^{2} \times 100 \%
$$

$\mathrm{Kd}$

$$
=(-0,81)^{2} \times 100 \%
$$

$\mathrm{Kd} \mathrm{x}_{2} \mathrm{y}$

$$
=65,61 \%
$$

Berdasarkan perhitungan diatas dapat disimpulkan bahwa, Harga terhadap loyalitas pelanggan memiliki konstribusi sebesar $65,61 \%$. Sedangkan sisanya $34,39 \%$ dipengaruhi oleh faktor-faktor lainnya yang tidak diteliti.

Koefisien Determinasi $\mathrm{X}_{1}$ dan $\mathrm{X}_{2}$ terhadap Y

Untuk mengetahui seberapa besar konstribusi yang diberikan kualitas produk dan harga terhadap loyalitas pelanggan maka dapat disimpulkan dengan koefisien determinasi sebagai berikut :

$$
\begin{aligned}
& \mathrm{Kd}=\left(\mathrm{r}_{12 \mathrm{y}}\right)^{2} \times 100 \% \\
& \mathrm{Kd}=(0,342)^{2} \times 100 \% \\
& \mathrm{Kd}=11,67 \%
\end{aligned}
$$

Berdasarkan perhitungan diatas dapat disimpulkan bahwa, Kualitas produk dan Harga terhadap loyalitas pelanggan memiliki konstribusi sebesar $11,67 \%$ Sedangkan sisanya $88,33 \%$ dipengaruhi oleh faktor-faktor lainnya yang tidak diteliti.

Uji Hipotesis (Uji t dan Uji f)

Uji t

Pengujian hipotesis dimaksudkan sebagai cara untuk menentukan suatu hipotesis apakah suatu hipotesa tersebut diterima atau ditolak. Rumus uji hipotesis sebagai berikut :

Hipotesis $\mathrm{X}_{1}$ terhadap $\mathrm{Y}$ 
Surianti

th $=r \sqrt{\frac{n-2}{1-r^{2}}}$

th $=0,12 \sqrt{\frac{94-2}{1-(0,12)^{2}}}$

th $=0,12(9,67)$

th $=1,160$

Berdasarkan hasil perhitungan di atas diperoleh $\mathrm{t}$ hitung 1,160 sedangkan $\mathrm{t}$ tabel dengan taraf keyakinan 5\% dan derajat kebebasan $\mathrm{dk}=\mathrm{n}-2=94-2=92, \mathrm{t}$ tabel $=1,980$. Karena $\mathrm{t}$ hitung lebih kecil dari t tabel yaitu sebesar $(1,160<$ 1,980), maka Ho diterima dan $\mathrm{Ha}$ ditolak, artinya "tidak ada pengaruh antara kualitas produk terhadap loyalitas pelanggan"

Hipotesis $\mathrm{X}_{2}$ terhadap $\mathrm{Y}$

th $=r \sqrt{\frac{n-2}{1-r^{2}}}$

th $=-0,81 \sqrt{\frac{94-2}{1-(-0,81)^{2}}}$

th $=-0,81(16,45)$

th $=-13,324$

Berdasarkan hasil perhitungan di atas diperoleh $\mathrm{t}$ hitung $(-13,324)$ sedangkan $t$ tabel dengan taraf keyakinan $5 \%$ dan derajat kebebasan $\mathrm{dk}=\mathrm{n}-2=94-2=92, \mathrm{t}$ tabel $=1,980$. Karena $t$ hitung lebih kecil dari t tabel yaitu sebesar $(-13,324<1,980)$, maka
Ho diterima dan Ha ditolak, artinya "tidak ada pengaruh antara harga terhadap loyalitas pelanggan".

Hipotesis $\mathrm{X}_{1}$ dan $\mathrm{X}_{2}$ terhadap $\mathbf{Y}$

$$
\text { th }=r \sqrt{\frac{n-2}{1-r^{2}}}
$$

$$
\begin{aligned}
& \text { th }=0,342 \sqrt{\frac{94-2}{1-(0,342)^{2}}} \\
& \text { th }=0,342(104,19) \\
& \text { th }=35,633
\end{aligned}
$$

Berdasarkan hasil perhitungan di atas diperoleh $t$ hitung 35,633 sedangkan $t$ tabel dengan taraf keyakinan $5 \%$ dan derajat kebebasan $\mathrm{dk}=\mathrm{n}-2=94-2=92$, maka $\mathrm{t}$ tabel $=1,980$. Karena $t$ hitung lebih besar dari t tabel yaitu sebesar $(35,633>1,980)$, maka Ha diterima dan Ho ditolak, artinya "ada pengaruh antara kualitas produk dan harga terhadap loyalitas pelanggan".

\section{Uji F}

Uji f dilakukan untuk mengetahui signifikan atau tidaknya pengaruh antara kualitas produk dan harga terhadap loyalitas pelanggan secara bersama-sama untuk menghitung uji $\mathrm{f}$ tersebut dapat menggunakan rumus sebagai berikut :

$\mathrm{Fh}=$ $\mathrm{R}^{2} / \mathrm{k}$ $\left(1-\mathrm{R}^{2}\right) /(\mathrm{n}-\mathrm{k}-1)$ 
Surianti

$$
\begin{aligned}
& \text { Fh }=\frac{(0,342)^{2} / 2}{(1-0,342) /(94-2-1)} \\
& F h=\frac{0,058^{0,007}}{F h=8,285^{0}}
\end{aligned}
$$

Berdasarkan perhitungan diatas diperoleh $\mathrm{F}$ hitung $=8,285$ untuk menentukan nilai $F$ tabel kesalahan yang digunakan sebesar 5\% dengan $\mathrm{dk}$ pembilang $=\mathrm{k}$ dan $\mathrm{dk}$ penyebut $=(\mathrm{n}-\mathrm{k}-$ 1) $=(94-2-1)=91$, maka $\mathrm{F}$ tabel $=3,10$ dan $\mathrm{F}$ hitung $=8,285$ karena, $\mathrm{f}$ hitung lebih besar dari $\mathrm{F}$ tabel yaitu sebesar $(8,285>3,10)$, maka Ho ditolak dan $\mathrm{Ha}$ diterima artinya terdapat pengaruh yang signifikan antara kualitas produk dan harga terhadap loyalitas pelanggan.

\section{KESIMPULAN}

1. Kualitas produk Floridina pada PT. Multi Inti Parahiyangan Depo Jatibarang masuk dalam kategori Baik, dilihat dari hasil perhitungan tanggapan responden mengenai kualitas produk Floridina sebesar $79,90 \%$.

2. Tingkat harga pada produk Floridina pada PT. Multi Inti Parahiyangan Depo Jatibarang sangat sesuai dengan harapan pelanggan, hal ini dapat dilihat dari hasil perhitungan tanggapan responden mengenai harga
Floridina yaitu mencapai 90,85\% termasuk ke dalam kategori Sangat Baik.

3. Loyalitas pelanggan pada produk Floridina di PT. Multi Inti Parahiyangan Depo Jatibarang sudah berjalan dengan baik yaitu mencapai 88,66 \% termasuk ke dalam kategori Sangat Baik.

4. Hubungan pengaruh kualitas produk Floridina terhadap loyalitas pelanggan PT. Multi Inti Parahiyangan masuk dalam kategori sangat rendah dan positif, dilihat dari hasil analisis korelasi antara kualitas produk terhadap loyalitas pelanggan yaitu $\mathrm{r} \times 1 \mathrm{y}=$ 0,12 dan adanya pengaruh kualitas produk terhadap loyalitas pelanggan dari hasil koefisien determinasi $\mathrm{kd} x 1 \mathrm{y}=$ sebesar $1,45 \%$ Sedangkan sisanya $\quad 98,55 \%$ dipengaruhi oleh faktor-faktor lainnya yang tidak diteliti. Uji hipotesis dengan menggunakan uji (t) diperoleh $\mathrm{t}$ hitung $\mathrm{x} 1 \mathrm{y}=1,160$ dan dari $t$ tabel dengan taraf keyakinan $5 \%$ dan derajat kebebasan $\mathrm{dk}=\mathrm{n}-2=94-2=92$, maka diketahui ttabel $=1,980$ sehingga thitung yaitu sebesar $(1,160<1,980)$ maka Hipotesis 
awal diterima dan Hipotesis alternatif ditolak.

5. Hubungan pengaruh harga produk Floridina terhadap loyalitas pelanggan PT. Multi Inti Parahiyangan masuk dalam kategori sangat kuat dan negative dapat dilihat dari hasil analisis korelasi antara harga terhadap loyalitas pelanggan yaitu $\mathrm{r} x 2 \mathrm{y}=(-$ $0,81)$ dan adanya pengaruh harga terhadap loyalitas pelanggan dari hasil koefisien determinasi $\mathrm{kd} \mathrm{x} 2 \mathrm{y}$ $=$ sebesar $65,61 \%$ Sedangkan sisanya $34,39 \%$ dipengaruhi oleh faktor-faktor lainnya yang tidak diteliti. Uji hipotesis dengan menggunakan uji $(\mathrm{t})$ diperoleh $\mathrm{t}$ hitung $\mathrm{x} 2 \mathrm{y}=(-13,324)$ dan dari $\mathrm{t}$ tabel dengan taraf keyakinan 5\% dan derajat kebebasan $\mathrm{dk}=\mathrm{n}-2=94-$ $2=92$, maka diketahui ttabel $=$ 1,980 sehingga thitung yaitu sebesar $(-13,324<1,980)$ maka Hipotesis alternatif diterima dan Hipotesis awal ditolak.

6. Tingkat pengaruh kualitas produk dan harga produk Floridina terhadap loyalitas pelanggan PT. Multi Inti Parahiyangan masuk dalam kategori rendah dan positif, dilihat dari hasil analisis korelasi antara harga terhadap loyalitas pelanggan yaitu $\mathrm{r} \times 1 \mathrm{x} 2 \mathrm{y}=0,342$ dan adanya pengaruh harga terhadap loyalitas pelanggan dari hasil koefisien determinasi $\mathrm{kd}$ $\mathrm{x} 1 \mathrm{x} 2 \mathrm{y}=11,67 \% \quad$ sedangkan sisanya $88,33 \%$ dipengaruhi oleh faktor-faktor lainnya yang tidak diteliti. Uji hipotesis dengan menggunakan uji (t) diperoleh $\mathrm{t}$ hitung $\mathrm{x} 1 \mathrm{x} 2 \mathrm{y}=35,633$ dan dari $\mathrm{t}$ tabel dengan taraf keyakinan 5\% dan derajat kebebasan $\mathrm{dk}=\mathrm{n}-2=94$ $2=92$, maka diketahui ttabel $=$ 1,980 sehingga thitung yaitu sebesar $(35,633>1,980)$ maka Hipotesis alternatif diterima dan Hipotesis awal ditolak.

7.

\section{DAFTAR PUSTAKA}

Amirullah, Pengantar Manajemen.; Fungsi, Proses, Pengendalian. Mitra Wacana Media. Jakarta, 2015.

Andri Feriyanto dan Endang Shyta Triana, Pengantar Manajemen (3 in 1). Mediatera. Yogyakarta, 2015.

A.a.Anwar Prabu Mangkunegara.Manajemen

Sumber Daya Manusia Perusahaan, PT. Remaja Rosdakarya, 2013.

Daft.Richard L, Era Baru Manajemen. Salemba Empat.Jakarta, 2010. 
Handoko Hani, Manajemen Personalia \& Sumberdaya Manusia. BPFEYogyakarta, 2014.

Hasibuan, MalayuS.P, Manajemen Sumber Daya Manusia. Bumi aksara.Jakarta, 2012.

Sutrisno Edy, Manajemen Sumber Daya Manusia. Kencana Prenada Media Group. Jakarta, 2014.

Sugiyono, Statistika untuk Penelitian. Alfabeta. Bandung, 2013.

Sugiyono, Metode Penelitian Administrasi. Alfabeta. Bandung, 2014. 